\title{
Effects of Almond Leaf Scorch Disease on Almond Yield: Implications for Management
}

\author{
Mark S. Sisterson and Jianchi Chen, United States Department of Agriculture-Agricultural Research Service \\ (USDA-ARS), San Joaquin Valley Agricultural Sciences Center, Parlier, CA 93611; Mario A. Viveros, University of \\ California Cooperative Extension, Bakersfield 93307; Edwin L. Civerolo and Craig Ledbetter, USDA-ARS, San \\ Joaquin Valley Agricultural Sciences Center; and Russell L. Groves, Department of Entomology, University of Wis- \\ consin, Madison 53706
}

\begin{abstract}
Sisterson, M. S., Chen, J., Viveros, M. A., Civerolo, E. L., Ledbetter, C., and Groves, R. L. 2008. Effects of almond leaf scorch disease on almond yield: Implications for management. Plant Dis. 92:409-414.

Almond leaf scorch (ALS) disease has been present in California's almond-growing regions for over 60 years. This disease is caused by the bacterium Xylella fastidiosa and the pathogen is vectored by xylem-feeding sharpshooters and spittlebugs. Currently, there are no effective management techniques that prevent trees from becoming infected. Within affected orchards throughout California's Central Valley, disease incidence and the risk of tree-to-tree spread appears to be low. Consequently, the decision to remove or keep infected trees depends on lost productivity. We compared yield and vitality between infected and uninfected almond for cvs. Sonora and Nonpareil. Sonora was examined at three sites over 3 years and Nonpareil was examined at one site over 2 years. Yields of ALS-affected trees were significantly lower for both cultivars, although yield losses of Sonora were proportionally greater than those of Nonpareil. Yields of infected trees did not decline incrementally over years; rather, they fluctuated similarly to those of uninfected trees. In addition, no infected trees died during the course of the study. These results are in direct contrast to previous anecdotal reports which suggest that yields of infected trees incrementally decline and infected trees eventually die. A simple economic model was developed to determine conditions under which rouging infected trees would increase returns. Based on the model, orchard age, yield loss due to infection, and the value of a maximally producing almond tree should be considered when deciding to remove ALS-affected trees.
\end{abstract}

Almond leaf scorch (ALS) disease has been present in California for over 60 years (2). The disease results from infection by the bacterium Xylella fastidiosa, which causes several other economically important plant diseases, including Pierce's disease of grape and oleander leaf scorch $(8,9)$. The bacterium is vectored by xylem-feeding sharpshooters and spittlebugs (14). Diseased trees have been present in California's Sacramento Valley for many years and only recently have become more prevalent in portions of the central and southern San Joaquin Valley (5). Disease incidence is typically low and effective strategies for preventing trees from becoming infected have yet to be developed $(1,5,14)$.

Because effective techniques to prevent infection are unavailable, growers must decide to keep or replace infected trees.

Corresponding author: M. Sisterson

E-mail: msisterson@fresno.ars.usda.gov

Accepted for publication 5 October 2007.

doi:10.1094/PDIS-92-3-0409

This article is in the public domain and not copyrightable. It may be freely reprinted with customary crediting of the source. The American Phytopathological Society, 2008.
This decision is a function of two components: the risk of infected trees serving as sources for in-field, secondary pathogen spread and yield losses due to infection. In ALS-affected orchards in the San Joaquin Valley, Groves et al. $(5,6)$ described patterns of diseased trees to be the result of primary spread from inoculum sources outside the orchard. Specifically, X. fastidiosa-infected trees frequently were associated with field borders adjacent to irrigated forage crops; habitats known to support sharpshooter insect vectors. Consequently, the risk of infected trees serving as sources of inocula for secondary spread appears low. Thus, the decision to keep or remove infected trees should focus primarily on yield losses due to infection.

Productivity of ALS-affected trees has been reported to steadily decline over time as the disease becomes fully systemic, and trees ultimately are expected to die within 3 to 8 years of symptom onset $(2,12,16)$. However, there are no data to corroborate these assertions. We report here on a 3year project that compared yields and vitality of ALS-affected and unaffected trees. Our objectives in this study were to describe patterns of yield loss over successive years and document the extent of tree mortality observed during the course of the study. Demonstration of lower yields of
ALS-affected trees relative to unaffected trees may lead growers to conclude that tree replacement will be in their best economic interests; therefore, we contextualize our empirical results by using a simple economic model as a decision tool to aid in determining whether to keep or replace infected trees.

\section{MATERIALS AND METHODS}

Study sites. Yield evaluations were made at three orchards located in central and southern portions of the San Joaquin Valley of California. Orchards A and B were located in Fresno County and orchard $\mathrm{C}$ was located in Kern County. The orchards differed in the year of planting, cultivar composition, and row spacing. Orchard A was established in 1989 and consisted of alternating rows of almond, Prunus amygdalus (Mill.) D.A. Webb (Rosaceae) cvs. NePlus and Sonora planted with $4.9 \mathrm{~m}$ between rows and 6.7 $\mathrm{m}$ within rows. Orchard B was established in 1990 and consisted of rows of Nonpareil between rows of Carmel and Sonora planted with $6.7 \mathrm{~m}$ between rows and 7.9 $\mathrm{m}$ within rows. Finally, orchard $\mathrm{C}$ was established in 1996 and consisted of rows of Nonpareil between rows of Fritz and Sonora planted with $7.3 \mathrm{~m}$ between rows and $6.1 \mathrm{~m}$ within rows. Orchards A and C were flood irrigated and Orchard B used microsprinklers. Orchards were managed by growers following practices typical for their area.

During the month of October in the 3year period 2003-05, orchards B and C were surveyed for the presence of ALSaffected trees. Orchard A was surveyed in 2004-05 only. Surveys were conducted by rating every tree on a scale of 1 to 4 for the presence of ALS symptoms ( 1 = no symptoms and $4=$ all scaffolds showing symptoms). Leaf samples from all trees suspected of being affected by ALS were collected and returned to the laboratory to confirm the presence of $X$. fastidiosa. In the laboratory, polymerase chain reaction (PCR) (11) and enzyme-linked immunosorbent assay (ELISA) were used to verify that symptomatic trees were indeed infected with $X$. fastidiosa following methods similar to those of Groves et al. (5). Trees that resulted in a positive diagnostic assay by both PCR and ELISA were con- 
sidered infected with $X$. fastidiosa. Infected and uninfected trees were selected for yield evaluations based on these surveys.

Yield and kernel quality comparisons. Within orchards and years, yield comparisons were made only for cultivars in which a minimum of $10 \mathrm{X}$. fastidios $a$-infected trees were detected. Consequently, cv. Sonora was evaluated in all three orchards and cv. Nonpareil was evaluated in orchard C (Table 1). Disease incidence was not sufficiently high in cvs. Fritz, NePlus, and Carmel to evaluate them in any of the orchards in which they were present (Table 1). The yield study began in 2004 and estimates were made for Sonora over 3 years (2004 to 2006), whereas yield estimates were made for Nonpareil for only 2 years (2004 to 2005).

For each orchard-cultivar combination, 10 ALS-affected trees were selected for yield estimates. Preference was given to using infected trees with the highest symptom rankings from our survey. Mean ( \pm standard deviation [SD]) symptom rankings for infected Sonora trees used in the study were $4 \pm 0.0,3.6 \pm 0.8$, and $3.6 \pm 1.0$ for Orchards A, B, and $\mathrm{C}$, respectively. Mean $( \pm \mathrm{SD})$ symptom rankings for infected Nonpareil trees used in the study was $3.1 \pm 1.3$ for Orchard C. The same infected trees were used each year of the study. Ten uninfected trees were selected randomly within the orchard to serve as controls. The same control trees were not used in each year of the study.
We estimated kilograms of almond kernel produced by each tree. This was a multistep process accomplished during the commercial harvest. Three to five days after almonds had been shaken to the ground, the total harvest weight was measured by weighing all almonds (hulls, shell, and kernels) and organic debris raked from underneath the canopy of selected trees using an industrial scale (Ohaus Model CW-11, Pine Brook, NJ). Two correction factors were required to eliminate the weight of organic debris, hulls, and shells from our harvest: the proportion of our harvest which was organic debris and hulls and the proportion of nut weight (shell + kernel) which was kernel. To estimate these correction factors, a 4-lb. subsample of harvested nuts and organic debris from each tree was returned to the laboratory. The proportion of the subsample which was organic matter and hulls was estimated by weighing the subsample after returning to the laboratory and then reweighing after removal of all organic debris and hulls. The proportion of nut weight which was kernel was estimated by weighing all nuts in the subsample, shelling the nuts, and then weighing the kernels only.

In addition, we evaluated several aspects of kernel quality. Twenty-five kernels from each tree were weighed to estimate kernel size. In addition, 200 kernels from each tree were examined and the number of kernels with inking, gumming, and dam- age resulting from infestation by the navel orangeworm, Amyelois transitella (Walker) (Lepidoptera: Pyralidae), was recorded.

Kilograms of kernel produced per tree and each measure of kernel quality were compared within cultivars and years using analysis of variance (18). For cv. Sonora, the model included orchard, infection status, and their interaction as factors. For cv. Nonpareil, the model included only infection status as a factor.

Cost thresholds for replacing infected trees. We developed a simple analytical model to determine conditions under which the cost of rouging would be warranted. This was accomplished by comparing the value of an infected tree with a replanted tree over the lifetime of an orchard. Descriptions of parameters are summarized in Table 2. We highlight several key assumptions. First, the orchard was assumed to be sufficiently mature so that trees produced their maximum yield (i.e., $>7$ years old). Second, newly replanted trees were assumed to produce lower yields than mature trees until replanted trees reached maturity. Third, infected trees did not die and yield loss due to infection was consistent over years. Fourth, the value of almonds was consistent over years. Finally, the lifetime of an orchard was finite.

The value of an infected tree $\left(V_{I}\right)$ over the lifetime of an orchard was estimated as average yield of an almond tree in kilograms $(Y)$, relative yield of an infected tree

Table 1. Incidence of Xylella fastidiosa infected trees and average symptom severity for infected trees at three study orchards in the central and southern San Joaquin Valley of California ${ }^{\text {w }}$

\begin{tabular}{|c|c|c|c|c|c|c|c|}
\hline \multirow[b]{2}{*}{ Orchard, county, cultivar } & \multirow[b]{2}{*}{ Trees $^{x}$} & \multicolumn{2}{|c|}{2003} & \multicolumn{2}{|c|}{2004} & \multicolumn{2}{|c|}{2005} \\
\hline & & No. infected & Mean rating & No. infected & Mean rating & No. infected & Mean rating \\
\hline \multicolumn{8}{|l|}{ A, Fresno } \\
\hline NePlus & 364 & $\ldots$ & $\ldots$ & 3 & 4 & 4 & 3.8 \\
\hline Sonora & 388 & $\ldots$ & $\ldots$ & 105 & 3.6 & $103^{y}$ & 3.6 \\
\hline \multicolumn{8}{|l|}{ B, Fresno } \\
\hline Carmel & 177 & 5 & 2.2 & 5 & 2.6 & $2^{\mathrm{y}}$ & 2 \\
\hline Nonpareil & 343 & 3 & 2.7 & 4 & 2.5 & 6 & 2.7 \\
\hline Sonora & 152 & 14 & 2.6 & 14 & 3.4 & $11^{\mathrm{y}}$ & 3.8 \\
\hline \multicolumn{8}{|l|}{ C, Kern } \\
\hline Fritz & 896 & 1 & 4 & 1 & 4 & 1 & 2 \\
\hline Nonpareil & 1,728 & 23 & 2.6 & 30 & 3.3 & 40 & 3.3 \\
\hline Sonora & $896^{z}$ & 53 & 3.4 & 61 & 3.5 & 72 & 3.5 \\
\hline
\end{tabular}

${ }^{\mathrm{w}}$ Trees were rated on a scale of 1 to 4 for the presence of almond leaf scorch ALS symptoms ( $1=$ no symptoms, $4=$ all scaffolds showing symptoms).

$\mathrm{x}$ Total number of trees.

${ }^{y}$ Declines in the number of infected trees between years were due to positive detections with polymerase chain reaction and enzyme-linked immunosorbent assay in one year but not in the following year.

${ }^{\mathrm{z}}$ In the winter of 2003-04, the grower removed 40 Sonora trees identified as being infected with $X$. fastidiosa. These trees were still used in counts of the number of infected trees during survey in 2004 and 2005.

Table 2. Parameters and default values used in the development of the simple analytical model

\begin{tabular}{llll}
\hline Parameter & \multicolumn{1}{c}{ Description } & Units & \multicolumn{1}{c}{ Default value } \\
\hline$V_{I}$ & Value of infected tree & Dollars & Equation 1 \\
$V_{R}$ & Value of replanted tree & Dollars & Equation 3 \\
$Y$ & Yield per uninfected tree & Kilograms & $9.1 \mathrm{~kg}$ \\
$P_{I}$ & Relative yield of an infected tree & See Results \\
$S$ & Sale price of a kg of almonds & Years & $\ldots$ \\
$R$ & Years until orchard is replaced & Years & $\ldots$ \\
$G$ & Years of yield loss due to replanting & Dollars & $\ldots 1.40$ (Nonpareil) \\
$C$ & Cost of replacing an infected tree & $\ldots$ & \\
\hline
\end{tabular}


to an uninfected tree $\left(P_{I}\right)$, sale price of a kilogram of almonds $(S)$, and number of years until the orchard was replaced $(R)$. Thus:

$V_{I}=Y \times P_{I} \times S \times R$

To estimate the value of a replanted tree $\left(V_{R}\right)$ over the lifetime of an orchard, the number of lost production years $(G)$ due to replanting must be estimated. This was estimated as:

$$
G=M-\sum_{a=0}^{a=M} P_{R, a}
$$

where $M$ was the number of years required for a tree to reach maturity. Years of yield loss during this period $(G)$ were determined by subtracting the sum of the relative yield of a newly replanted tree compared with a mature tree $\left(P_{R}\right)$ based on its age, $a$, over the period of maturation.

The value of a replanted tree $\left(V_{R}\right)$ over the lifetime of an orchard then was estimated as the gains due to replanting minus the cost of replanting. Thus:

$V_{R}=Y \times S \times(R-G)-C$

Gains over the lifetime of the orchard due to replanting were the product of three terms. The first two terms were the average yield of an almond tree $(Y)$ and the sale price per kilogram of almonds $(S)$. The third term was the difference between the number of years until the orchard is replanted $(R)$ and the number of lost production years due to replanting $(G)$. Gains due to replanting were offset by the costs associated with physically removing an infected tree, purchasing a replacement tree, and planting the replacement tree $(C)$.
If the value of a replanted tree $\left(V_{R}\right)$ is greater than the value of an infected tree $\left(V_{I}\right)$, replanting is warranted. Thus, growers should replant if:

$V_{R}-V_{I}>0$

eq. 4

Inserting equations 1 and 3 into equation 4 and solving for the cost of replacing an infected tree gives:

$C<S \times Y \times\left[R \times\left(1-P_{I}\right)-G\right]$

eq. 5

Thus, the costs associated with rouging are warranted provided they are less than the term on the right side of the inequality.

\section{RESULTS}

Yield and kernel quality comparisons. For cv. Sonora, there was a significant effect of infection status (Fig. 1A-C; 2004, $F=80.7, \mathrm{df}=1.52, P<0.0001 ; 2005, F=$ $33.9, \mathrm{df}=1,54, P<0.0001$; and 2006, $F=$ 34.2, $\mathrm{df}=1,53, P<0.0001)$ and orchard (2004, $F=22.6$, df $=2,52, P<0.0001$; 2005, $F=89.9$, df $=2$, 54, $P<0.0001$; and 2006, $F=98.2$, df $=2,53, P<0.0001)$ on yield in each year of study. The siteinfection status interaction was significant only during the third year of study (2004, $F=1.7$, df $=2,52, P=0.20 ; 2005, F=$ 2.7, df $=2,54, P=0.08$; and 2005, $F=$ $5.2, \mathrm{df}=2,53, P=0.009)$. For cv. Nonpareil, infection status significantly reduced yield in both years of study (Fig. 1D; 2004, $F=31.0, \mathrm{df}=1,18, P<0.0001$ and 2005, $F=4.2, \mathrm{df}=1,18, P=0.056)$.

Averaged across sites and years, infected Sonora trees produced $40 \%$ fewer kilograms of kernel than uninfected trees (Fig. 1A-C). Averaged across years, in- fected Nonpareil trees produced 19\% fewer kilograms of kernel than uninfected trees (Fig. 1D). For both cultivars, yields of infected trees did not decline incrementally over years and trends in yield mirrored those of uninfected trees (Fig. 1). No ALS-affected Sonora or Nonpareil trees died during the study.

Kernels produced by ALS-affected Sonora trees were significantly lighter than kernels produced by unaffected Sonora trees in 2 of 3 years of study (Table 3). Likewise, kernels produced by ALS-affected Nonpareil trees were significantly lighter in 1 of 2 years of study (Table 3). Averaged across sites and years, kernels produced by infected Sonora trees were $7.6 \%$ lighter than kernels produced by uninfected Sonora trees. Averaged over years, weight of kernels from ALS-affected Nonpareil trees was $4.5 \%$ lighter than for kernels from unaffected Nonpareil trees. Inking was significantly more prevalent in uninfected Sonora trees than infected trees in 2 of 3 years of study (Table 3 ). This effect was not observed in Nonpareil. There were no consistent associations of ALS with gumming or navel orangeworm damage for either cultivar.

Cost thresholds for replacing infected trees. The cost threshold that would warrant replacing an infected tree depended on several factors, including the sale price of almonds $(S)$, average yield of an almond tree $(Y)$, the number of years until the entire orchard is replaced $(R)$, the relative yield of infected trees to uninfected trees $\left(P_{I}\right)$, and the number of lost production
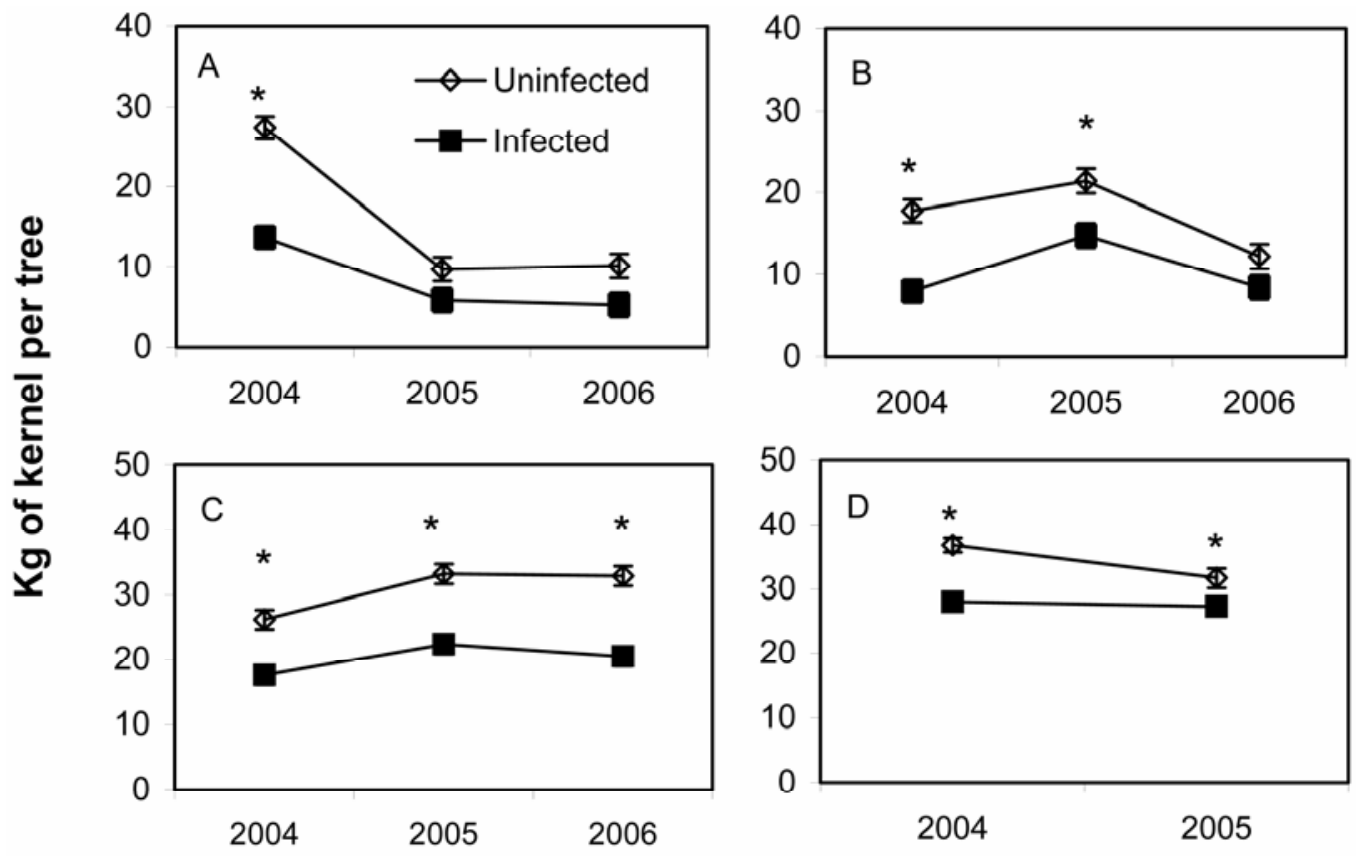

\section{Year}

Fig. 1. Least square mean ( \pm standard error) yield of unaffected and almond leaf scorch-affected trees. A, B, and C, Yield of Sonora trees at Orchards A, B, and C, respectively. D, Yield of Nonpareil trees at Orchard C. Within years and orchards, significant differences between uninfected and infected trees are indicated by an asterisk. 
years while replanted trees matured $(G)$ (see equation 5).

Based on equation 5, infected trees should never be replaced if the yield loss due to replanting exceeds the yield loss due to keeping an infected tree over the lifetime of the orchard (i.e., $G>R \times[1-$ $\left.P_{I}\right]$ ). Clearly, replanting an infected tree would never be cost effective if the entire orchard were replaced before a replanted tree produced yields that were at least equivalent to the infected tree it replaced. Thus, higher replanting costs are acceptable for young orchards compared with old orchards (i.e., as $R$ increases; Fig. 2). For Sonora, the model suggests that tree re- placement is unwarranted unless the orchard will be in production for at least another 10 years (Fig. 2A and C). For Nonpareil, this timeframe was 20 years (Fig. 2B and D). The cost of tree replacement is likely to be low, $\$ 5.00$ for the replacement tree plus labor costs to remove the infected tree (3). Consequently, replac-

Table 3. Least square mean ( \pm standard error) weight of 25 kernels and the mean percentage of kernels with inking, gumming, and navel orangeworm (NOW) damage

\begin{tabular}{|c|c|c|c|c|c|c|}
\hline \multirow[b]{3}{*}{ Cultivar, measure $^{\mathrm{z}}$} & \multicolumn{6}{|c|}{ Year $^{\mathrm{y}}$} \\
\hline & \multicolumn{2}{|c|}{2004} & \multicolumn{2}{|c|}{2005} & \multicolumn{2}{|c|}{2006} \\
\hline & Uninfected & Infected & Uninfected & Infected & Uninfected & Infected \\
\hline \multicolumn{7}{|l|}{ Sonora } \\
\hline Weight of 25 kernels & $33.5 \pm 0.6 \mathrm{a}$ & $29.3 \pm 0.6 b$ & $37.9 \pm 0.4 \mathrm{a}$ & $35.0 \pm 0.4 \mathrm{~b}$ & $32.1 \pm 0.5 \mathrm{a}$ & $31.3 \pm 0.5 \mathrm{a}$ \\
\hline Inking (\%) & $1.2 \pm 0.2 \mathrm{a}$ & $0.9 \pm 0.2 \mathrm{a}$ & $6.2 \pm 0.5 \mathrm{a}$ & $2.3 \pm 0.5 b$ & $8.3 \pm 0.8 \mathrm{a}$ & $4.5 \pm 0.8 \mathrm{~b}$ \\
\hline Gumming (\%) & $1.5 \pm 0.3 \mathrm{a}$ & $1.3 \pm 0.3 \mathrm{a}$ & $0.4 \pm 0.1 \mathrm{a}$ & $0.4 \pm 0.1 \mathrm{a}$ & $3.7 \pm 0.7 \mathrm{a}$ & $6.3 \pm 0.7 b$ \\
\hline NOW damage (\%) & $18.9 \pm 0.9 \mathrm{a}$ & $19.2 \pm 0.9 \mathrm{a}$ & $4.2 \pm 0.5 \mathrm{a}$ & $5.7 \pm 0.5 b$ & $10.2 \pm 0.6 \mathrm{a}$ & $9.2 \pm 0.6 \mathrm{a}$ \\
\hline \multicolumn{7}{|l|}{ Nonpareil } \\
\hline Weight of 25 kernels & $24.5 \pm 0.3 \mathrm{a}$ & $22.8 \pm 0.3 b$ & $28.5 \pm 0.5 \mathrm{a}$ & $27.9 \pm 0.5 \mathrm{a}$ & $\ldots$ & $\ldots$ \\
\hline Inking (\%) & $0.0 \pm 0.0 \mathrm{a}$ & $0.0 \pm 0.0 \mathrm{a}$ & $0.5 \pm 0.2 \mathrm{a}$ & $0.3 \pm 0.2 \mathrm{a}$ & $\ldots$ & $\ldots$ \\
\hline Gumming (\%) & $0.0 \pm 0.0 \mathrm{a}$ & $0.1 \pm 0.1 \mathrm{a}$ & $0.0 \pm 0.0 \mathrm{a}$ & $0.0 \pm 0.0 \mathrm{a}$ & $\ldots$ & $\ldots$ \\
\hline NOW damage (\%) & $4.6 \pm 0.5 \mathrm{a}$ & $6.5 \pm 0.5 b$ & $1.8 \pm 0.3 \mathrm{a}$ & $1.7 \pm 0.3 \mathrm{a}$ & $\ldots$ & $\ldots$ \\
\hline
\end{tabular}

${ }^{y}$ Within years, comparisons between kernels collected from uninfected and infected trees which are significantly different are indicated by different letters and are bolded.

${ }^{\mathrm{z}}$ For cv. Sonora, means across orchards were calculated; weight of 25 kernels measured in grams.

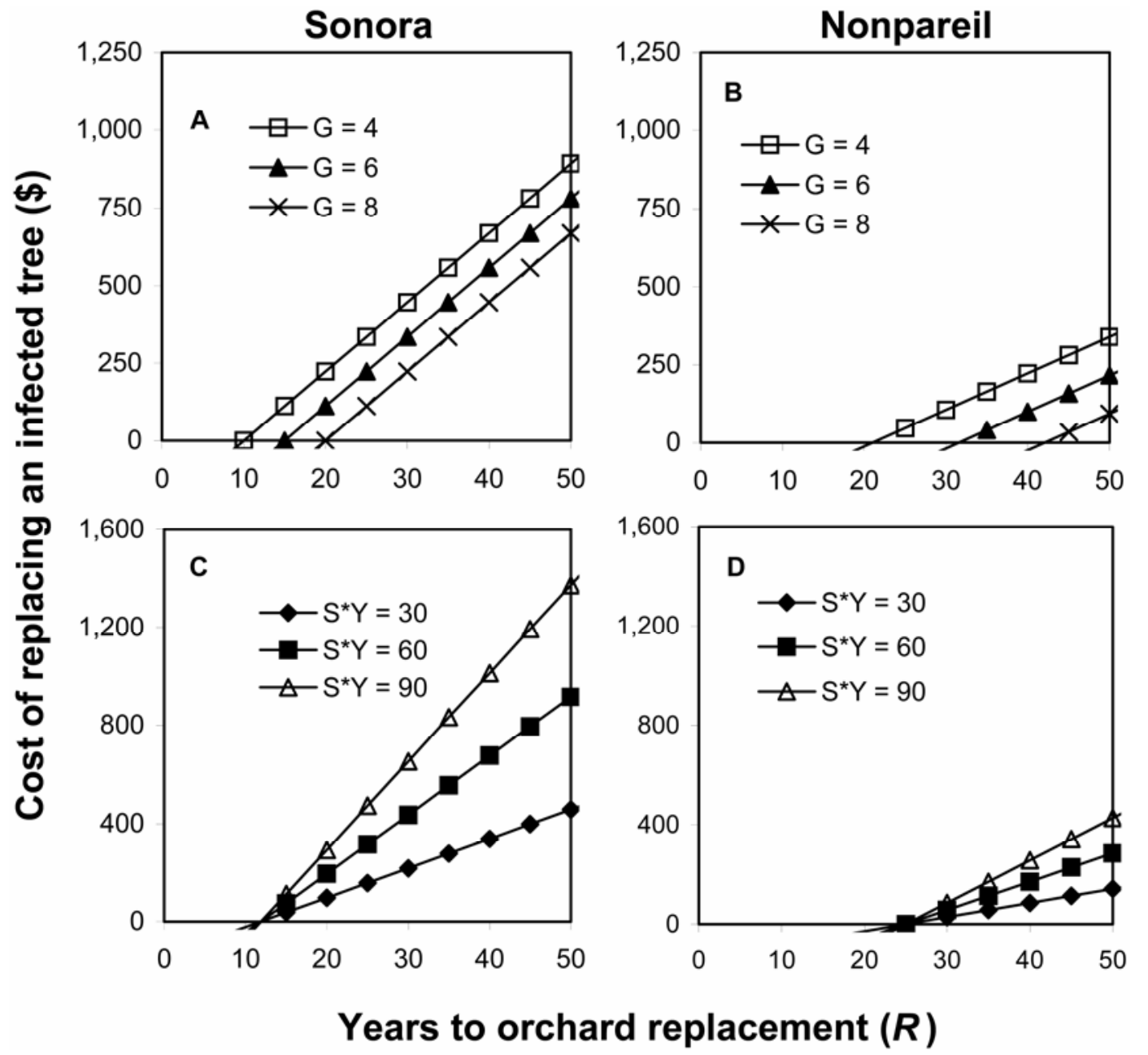

Fig. 2. Results of economic model parameterized for yield reductions observed for the cultivars Sonora, $\mathbf{A}$ and $\mathbf{C}$, and Nonpareil, $\mathbf{B}$ and $\mathbf{D}$, under different assumptions for the years to orchard replacement $(R)$, years of yield loss due to the time required for a replanted tree to mature $(G)$, and the annual return in dollars for an uninfected almond tree $(S \times Y)$. Replanting is economically beneficial provided that the cost of replanting falls below a line. Values were calculated using equation 5. All parameters not varied in a panel were set to their default value. 
ing infected trees in very young orchards would be warranted.

Higher replanting costs are acceptable for cultivars that exhibit severe reductions in yield due to ALS compared with cultivars that are less affected. For example, higher replanting costs are more acceptable for Sonora compared with Nonpareil because yield loss due to infection was estimated to be greater for Sonora than Nonpareil (compare Fig. 2A and $\mathrm{C}$ to $\mathrm{B}$ and D).

Higher costs associated with replanting are acceptable as the quotient of value of almonds and kilograms of almonds produced per tree increases (Fig. 2C and D). This value $(S \times Y)$ represents annual return in dollars of an uninfected almond tree. Thus, greater costs associated with replanting are acceptable for cultivars that produce high yields or have high value.

\section{DISCUSSION}

In this study, yields of ALS-affected trees were lower than those of unaffected trees and degree of yield loss depended on almond cultivar (Fig. 1). A portion of this difference was due to production of lighter kernels by infected trees (Table 3), although other aspects of kernel quality were not consistently impacted (Table 3 ). Yield reductions reported here indicate that infection of almond trees by $X$. fastidiosa causes substantial yield loss. However, removal of infected trees will not always be economically beneficial because yields from infected trees could provide greater returns than replanted trees (Fig. 2).

Previous studies anecdotally reported that yields of infected trees should incrementally decline over years and infected trees should die within 3 to 8 years of symptom onset $(2,12,16)$. Neither effect was observed over the 3 years of our study. In fact, no infected trees died and yields of infected trees over years mirrored trends in uninfected trees (Fig. 1). Infection dates for ALS-affected trees selected in our study are unknown. Thus, the trees were infected for a minimum of 3 years but are likely to have been infected for more than 3 years. In fact, most ALS-affected trees selected at the beginning of the harvest study (2003) were rated as trees possessing fully-systemic symptoms on all scaffolds (rating $=4$ ). This suggests a history of $X$. fastidiosa infection within trees that preceded our initial survey by at least 1 to 3 years (14). Although we cannot predict what would occur if our study was extended for another 4 years, our results do cast doubt on the broad applicability of previous anecdotal reports. The differences between our observations and previous reports could be due to differences in the cultivars examined, pathogen strains, or any number of environmental or cultural practices different between our study and those observations made over 30 years ago. No data were presented in these anec- dotal reports; thus, such comparisons cannot be fully evaluated.

Many diseases caused by X. fastidiosa are known to kill infected hosts. For example, Pierce's disease of grape kills highly susceptible cultivars within a few years of infection (4). However, not all plants which display symptoms die. For example, the $X$. fastidiosa-caused disease pecan bacterial leaf scorch reduces yield but infected trees typically are not killed by the pathogen (17). Importantly, Sanderlin and Keyderich-Alger (17) hypothesized that infected pecan may be more susceptible to environmental stresses such as fall freezes which could cause tree mortality during abnormally cold falls. Such interactions of ALS with rare environmental events may occur and could be a possible explanation for observance of tree death in previous reports. Likewise, ALS may make trees more susceptible to any number of other pathogens or stresses which were not observed during the course of our study (8).

Our model indicates that several criteria should be considered before an ALSaffected tree is removed (Fig. 2). There are a number of implicit assumptions in the model that must be emphasized. First, based on our empirical results, infected trees were assumed to not die and yield loss due to infection was consistent over years. Clearly, if longer-term evaluations or evaluations of other cultivars produce different results, these assumptions would need revision. Second, tree-to-tree spread of the pathogen was assumed to pose little risk. Incidence of ALS is typically low in affected orchards and infected trees have been described as either randomly distributed within orchards (1) or in groups distributed along field edges resulting from primary pathogen spread (5). However, higher levels of disease incidence occasionally are reported (13). If the apparent risk of tree-to-tree or secondary pathogen spread within an orchard appears greater, such risk should be taken into consideration.

The epidemiology of ALS in the almond-growing regions of California may change in the future due to the introduction of an exotic vector of $X$. fastidiosa. The glassy-winged sharpshooter, Homalodisca vitripennis (Germar) (Hemiptera: Cicadellidae), is now established in portions of southern California (1). Range expansion of this vector into the almond-growing regions of California may increase disease incidence and the risk of tree-to-tree spread (15). Currently, such a range expansion appears unlikely due to the success of an intensive area-wide control program in southern California $(7,19,20)$. Further, it is unclear how well this vector is suited for the cooler climates of the San Joaquin and Sacramento Valleys of California (10). Nonetheless, the possibility for such a range expansion cannot be excluded and adjustment of management tactics for ALS would be necessary if range expansion occurred.

In conclusion, ALS-affected trees produced lower yields than unaffected trees and the decision to replace infected trees should be made on a case-by-base basis. Disease development or expression was different in the two cultivars examined here, indicating that extrapolation of our results to other cultivars would not be justified. Thus, future work should examine other cultivars. Our results cast doubt on anecdotal claims that ALS kills affected trees. However, longer-term studies are required to conclusively demonstrate the risk of ALS on tree death.

\section{ACKNOWLEDGMENTS}

We thank the Almond Board of California for partially funding this research under agreements 04-RG-01, 05-RG-01, and 06-RG-01; J. Cabrera, T. De la Torre, D. Dwyer, P. Sahota, M. Schreiber, and S. Uchima for technical assistance with this work; and G. Favagrossa, J. Neely, and D. Ehlrich for their assistance and hospitality in the use of their respective orchards for experimentation.

\section{LITERATURE CITED}

1. Almeida, R. P. P., and Purcell, A. H. 2003. Homalodisca coagulata (Hemiptera, Cicadellidae) transmission of Xylella fastidiosa to almond. Plant Dis. 87:1255-1259.

2. Almond Board of California (ABC). 2004 Years of Discovery: A Compendium of Production and Environmental Research Projects, 1972-2003. Almond Board of California, Modesto.

3. Duncan, R. A., Verdegaal, P. S., Holtz, B. A., Klonsky, K. A., and De Moura, R. L. 2006. Sample costs to establish an orchard and produce almonds: San Joaquin Valley North, flood irrigation. Univ. Calif. Coop. Ext. Publ. No. AM-VN-06-1.

4. Goodwin, P., and Purcell, A. H. 1992. Pierce's disease. Pages 76-84 in: Grape Pest Management, 2nd ed. Division of Agriculture and Natural Resources, University of California, Oakland.

5. Groves, R. L., Chen, J., and Civerolo, E. L. 2005. Spatial analysis of almond leaf scorch disease in the San Joaquin Valley of California: factors affecting pathogen distribution and spread. Plant Dis. 89:581-589.

6. Groves, R, L., Sisterson, M., Chen, J., and Lin, H. 2006. Epidemiology of almond leaf scorch disease in the San Joaquin Valley of California factors affecting pathogen distribution and movement. Pages 176-183 in: Proc. 34th Almond Ind. Conf.

7. Hix, R. L, Toscano, N. C., and Gispert, C. 2003. Area-wide management of the glassywinged sharpshooter in the Temecula and Coachella valleys. Pages 292-294 in: Proc. Pierce's Dis. Res. Symp.

8. Hopkins, D. L. 1989. Xylella fastidiosa: xylem-limited bacterial pathogen of plants. Annu. Rev. Phytopathol. 27:271-290.

9. Hopkins, D. L., and Purcell, A. H. 2002. Xy lella fastidiosa: cause of Pierce's disease of grapevine and other emergent diseases. Plant Dis. 86:1056-1066.

10. Johnson, M. W., Daane, K., Groves, R., Backus, E., and Son. 2005, Y. Spatial population dynamics and overwintering biology of the glassy-winged sharpshooter in California's San Joaquin Valley. Pages 113-116 in: Proc. Pierce's Dis. Res. Symp.

11. Minsavage, G. V., Thompson, C. M., Hopkins, D. L., Leite, R. M. V. B. C., and Stall, R. E. 
1994. Development of a polymerase chain reaction protocol for detection of Xylella fastidiosa in plant tissue. Phytopathology 84:456461.

12. Mircetich, S. M., Lowe, S. K., Moller, W. J., and Nyland, G. 1976. Etiology of almond leaf scorch disease and transmission of the causal agent. Phytopathology 66:17-24.

13. Moller, W. J., Sanborn, R. R., Mircetich, S. M., Williams, H. E., and Beutel, J. A. 1974. A newly recognized and serious leaf scorch disease of almond. Plant Dis. Rep. 58:99-101.

14. Purcell, A. H. 1980. Almond leaf scorch: leafhopper and spittlebug vectors. J. Econ. Entomol. 73:834-838.

15. Purcell, A. H., and Saunders, S. R. 1999. Glassy-winged sharpshooters expected to increase plant disease. Calif. Agric. 53:26-27.

16. Sanborn, R. R., Mircetich, S. M., Nyland, G., and Moller, W. J. 1974. "Golden death" a new leaf scorch threat to almonds growers. Calif. Agric. 28:4-5.

17. Sanderlin, R. S., and Heyderich-Alger, K. I. 2003. Effects of pecan bacterial leaf scorch on growth and yield components of cultivar cape fear. Plant Dis. 87:259-262.
18. SAS Institute. 2002. JMP Statistics and Graphics Guide. SAS Institute, Cary, NC.

19. Stone-Smith, B., Stewart-Leslie, J., Kunkel, G., Hardy, S., Appleby, B., Borges, D., Haines, D., and Churchill, J. 2005. The area-wide pest management of glassy-winged sharpshooter in Tulare County. Pages 376-377 in: Proc. Pierce's Dis. Res. Symp.

20. Toscano, N. C., Hix, R., and Gispert, C. 2004. Riverside County glassy-winged sharpshooter area-wide management program in the Coachella and Temecula Valleys. Pages 375-377 in: Proc. Pierce's Dis. Res. Symp. 